\title{
Status Ketahanan Pangan dan Faktor Sosio-Ekonomi pada Masyarakat Pesisir Kabupaten Buru Selatan
}

\author{
Food Security Status and Socio-Economic Factors of The Coastal Community in Buru Selatan District \\ Christiana Rialine Titaley ${ }^{1 *}$, Ninik Ma'athia Sallatalohy ${ }^{1}$, Felecia Petrosina Adam ${ }^{2}$ \\ ${ }^{1}$ Fakultas Kedokteran, Universitas Pattimura Ambon, Jl. Ir. M. Putuhena, \\ Kampus Poka, Ambon 97233, Indonesia \\ 2Program Studi Agribisnis, Jurusan Budidaya Pertanian, Fakultas Pertanian, Universitas Pattimura, \\ Jl. Ir. M. Putuhena, Kampus Poka, Ambon, 97233, Indonesia \\ *Penulis korespondensi: Christiana R.T., Email: christiana_rialine@yahoo.com
}

Tanggal submisi: 14 Juli 2018; Tanggal penerimaan: 30 September 2019

\begin{abstract}
ABSTRAK
Ketahanan pangan merupakan salah satu isu global terutama di negara berkembang, termasuk Indonesia. Studi ini bertujuan untuk menganalisis status ketahanan pangan serta faktor-faktor yang berhubungan, pada masyarakat di wilayah pesisir Kabupaten Buru Selatan, Provinsi Maluku. Studi ini menggunakan data yang berasal dari survei kesehatan masyarakat di wilayah pesisir Buru Selatan, Maluku. Survei dilakukan oleh Fakultas Kedokteran, Universitas Pattimura pada bulan November 2017, melalui wawancara dengan 899 responden usia 20-60 tahun. Status ketahanan pangan dinilai dengan menggunakan kuesioner US Household Food Security/ Hunger Survey Module (USFSSM). Berbagai faktor mulai dari tingkat lingkungan, rumah tangga, dan individu disertakan dalam analisis ini. Metode regresi logistik multivariat digunakan untuk mengetahui faktor-faktor yang berhubungan dengan status ketahanan pangan masyarakat. Hasil penelitian didapatkan, dari 899 responden yang diwawancarai, hanya $30 \%$ yang tahan pangan dan $70 \%$ mengalami rawan pangan. Sebanyak $33,7 \%$ responden mengalami rawan pangan dengan kondisi lapar. Responden di Kecamatan Waesama lebih tahan pangan dibandingkan Kecamatan Kepala Madan ( $\mathrm{aOR}=2,16$, 95\%CI: 1,33-3,52, $p=0,002$ ). Responden dari rumah tangga "sangat kaya" lebih dari tiga kali lebih tahan pangan dari rumah tangga "sangat miskin" (aOR=3,49, 95\%CI: $2,13-5,73, p<0,001)$. Responden yang harus membayar kepesertaan iuran kesehatan juga lebih tahan pangan dibandingkan yang mendapatkan pembebasan pembayaran iuran dari pemerintah (aOR=1,49, 95\%CI: 1,07-2,08, $p=0,018$ ). Hasil penelitian juga diperoleh bahwa responden yang tinggal di rumah dengan kepadatan anggota rumah tangga ideal ( $\geq 8 \mathrm{~m}^{2}$ per orang) lebih tahan pangan dibandingkan mereka dari rumah dengan kepadatan anggota rumah tangga kurang ideal ( $\mathrm{aOR}=1,55,95 \% \mathrm{CI}: 1,01-2,39, p=0,047)$. Penelitian ini menunjukkan bahwa kerjasama lintas sektor sangat diperlukan dalam upaya meningkatkan ketahanan pangan masyarakat. Intervensi yang bertujuan untuk menurunkan angka kemiskinan serta penyediaan pangan bersubsidi, termasuk pangan terfortifikasi, bagi masyarakat yang membutuhkan dengan didukung program edukasi bagi masyarakat sangat penting untuk dilakukan di wilayah pesisir Kabupaten Buru Selatan.
\end{abstract}

Kata kunci: Faktor yang berhubungan; Kabupaten Buru Selatan; masyarakat pesisir; ketahanan pangan; Maluku

\begin{abstract}
Food security was one of the global issues, especially in developing countries, including Indonesia. This study aimed to examine the status of food security and its related factors in the coastal communities in the area of Buru Selatan District, Maluku Province. This study used secondary data collected from a household health survey conducted by the Faculty of Medicine, Pattimura University in November 2017. Information is derived from 899
\end{abstract}


respondents aged 20-60 years. Food security status was measured using the US Household Food Security/Hunger Survey Module (USFSSM). Factors ranging from environmental, household and individual levels are included in the analysis. Logistic regression method was applied to determine factors associated with food security status. Of the 899 respondents interviewed, only 30\% was food secured and about 70\% suffered fromfood insecurity $(33,7 \%$ experienced food insecurity with hunger). Respondents from Waesama Sub-district were more food secured than those from Kepala Madan Sub-district ( $\mathrm{aOR}=2,16,95 \% \mathrm{CI}: 1,33-3,52, p=0,002)$. Respondents from "very rich" households were three and a half times more food-secured than "very poor" households $(\mathrm{aOR}=3,49$, $95 \%$ CI: $2,13-5,73, p<0,001)$. In addition, those who paid for the membership of health insurance were more food secured than those who got waived payment of contributions ( $\mathrm{aOR}=1,49,95 \% \mathrm{CI}: 1,07-2,08, p=0.018$ ); and respondents living in an ideal household density ( $8 \mathrm{~m}^{2}$ or more per person) were more food secured than those innot ideal condition ( $\mathrm{aOR}=1,55,95 \% \mathrm{CI}: 1,01-2,39, p=0,047)$. Our study showed that intersectoral collaboration is important to improve community's food security status. Long and short term interventions aimed at reducing poverty and providing subsidized foods, including fortified ones, to the those in need accompanied by educational programs to improve community knowledge about various alternative of local food are essential.

Keywords: Associated factors; Buru Selatan District; coastal community; food security; Maluku

\section{PENDAHULUAN}

Ketahanan pangan merupakan salah satu isu global terutama di negara berkembang termasuk Indonesia. Ketahanan Pangan menurut Undang-Undang Republik Indonesia Nomor 18 Tahun 2012 merupakan "kondisi terpenuhinya pangan bagi negara sampai dengan perseorangan, yang tercermin dari tersedianya pangan yang cukup, baik jumlah maupun mutunya, aman, beragam, bergizi, merata, dan terjangkau serta tidak bertentangan dengan agama, keyakinan, dan budaya masyarakat, untuk dapat hidup sehat, aktif, dan produktif secara berkelanjutan"(Anonim, 2012).

Sebagai bagian dari agenda Sustainable Development Goals (Tujuan Pembangunan Berkelanjutan) terkait upaya penghapusan kelaparan (Goal \#2) (United Nations, 2015), tiga komponen utama ketahanan pangan adalah ketersediaan pangan, akses pangan serta pemanfaatan zat gizi dalam pangan (Abdullah dkk., 2017). Ketahanan pangan meliputi dimensi global, regional, nasional, sampai level rumah tangga dan individu (Food and Agriculture Organization of the United Nations, 2013; Food and Agriculture Organization of the United Nations 2017). Berbagai faktor yang dilaporkan berhubungan dengan status ketahanan pangan termasuk kondisi ekonomi rumah tangga, tingkat pendidikan, pengetahuan mengenai penyimpanan dan pengolahan makanan, kesuburan lahan, akses irigasi, krisis air global, perubahan lahan sampai perubahan iklim (Food and Agriculture Organization of the United Nations, 2013; Mannaf Maksuda \& Uddin Md. Taj, 2012; Wambua dkk., 2014).

Berbagai dampak kerawanan pangan terhadap status kesehatan telah banyak dilaporkan baik pada anak maupun orang dewasa (Ke \& Ford-Jones, 2015;
Seligman dkk., 2010). Salah satu contoh dampak peningkatan kerawanan pangan adalah meningkatnya proporsi kurang gizi menjadi $12 \%$ dari total populasi dunia (Abdullah dkk., 2017). Di Asia Tenggara, proporsi kurang gizi diperkirakan mencapai hampir 35\% kasus kurang gizi yang terjadi di dunia (Food and Agriculture Organization of the United Nations, 2013). Selain itu, terjadinya anemia defisiensi besi akibat kerawanan pangan dilaporkan menjadi salah satu penyebab penurunan kemampuan belajar dan produktivitas (Black, 2012). Kerawanan pangan juga dilaporkan berhubungan dengan peningkatkan penyakit kronik dan risiko obesitas pada anak (Dubois dkk., 2011; Garner \& Shonkoff, 2012; Gundersen, dkk., 2008). Di kalangan remaja, berbagai studi menyebutkan hubungan kerawanan pangan dengan kejadian depresi, perubahan perasaan, perilaku bahkan sampai pada penggunaan obat terlarang (McIntyre dkk., 2012). Kerawanan pangan juga dilaporkan berhubungan dengan tingginya risiko ganggungan depresi pada kelompok maternal (McLaughlin dkk., 2012). Studi lain menunjukkan adanya peningkatkan risiko penyakit kardiovaskular (Seligman dkk., 2010) pada kelompok yang mengalami rawan pangan.

Dewasa ini, walaupun terkenal dengan mata pencaharian penduduknya sebagai petani atau bercocok tanam, Indonesia justru menghadapi masalah serius dalam situasi pangan. Hal ini tercermin melalui Global Food Security Index yang menempatkan status ketahanan pangan (keterjangkauan, ketersediaan, serta kualitas dan keamanan) Indonesia di peringkat ke-69 dari 113 negara (Anonim, 2017). Di Provinsi Maluku, dari 1057 desa, 35\% termasuk dalam Prioritas 1 dan 2 untuk desa yang cenderung sangat rentan terhadap kerawanan pangan dan gizi (Dinas Ketahanan Pangan 
Provinsi Maluku, 2017). Lima kabupaten dengan persentase terbesar desa dengan Prioritas 1 dan 2 di Provinsi Maluku adalah Kepulauan Aru (68,07\%), Maluku Barat Daya (48,72\%), Seram Bagian Timur (48,13\%), Buru Selatan (39,5\%), dan Maluku Tenggara Barat $(35,45 \%)$ (Dinas Ketahanan Pangan Provinsi Maluku, 2017).

Pada tahun 2017, Fakultas Kedokteran, Universitas Pattimura melaksanakan kegiatan survei pola penyakit pada masyarakat yang tinggal di wilayah pesisir di Kabupaten Buru Selatan. Salah satu informasi yang dikumpulkan adalah data ketahanan pangan yang dinilai dengan menggunakan kuesioner US Household Food Security/Hunger Survey Module (USFSSM) (Bickel dkk., 2000). Penelitian yang dilaksanakan dalam tulisan ini bertujuan untuk menganalisis status ketahanan pangan serta faktor-faktor yang berhubungan pada masyarakat pesisir Kabupaten Buru Selatan, Provinsi Maluku. Hasil analisis ini diharapkan dapat menjadi masukan bagi para pemangku kepentingan dan pengambil kebijakan dalam merancang dan mengimplementasikan intervensi suportif berbasis bukti untuk menurunkan angka rawan pangan pada masyarakat pesisir di Kabupaten Buru Selatan, serta wilayah lain di Provinsi Maluku.

\section{METODE PENELITIAN}

\section{Rancangan Studi}

Studi ini menggunakan data sekunder yang berasal dari survei kesehatan wilayah pesisir di Kabupaten Buru Selatan oleh Fakultas Kedokteran Universitas Pattimura pada bulan November 2017. Data yang digunakan dalam penelitian ini berasal dari survei yang dilakukan di lima lima kecamatan pesisir, Kecamatan Namrole, Leksula, Waesama, Kepala Madan, dan Ambalau (Gambar 1).

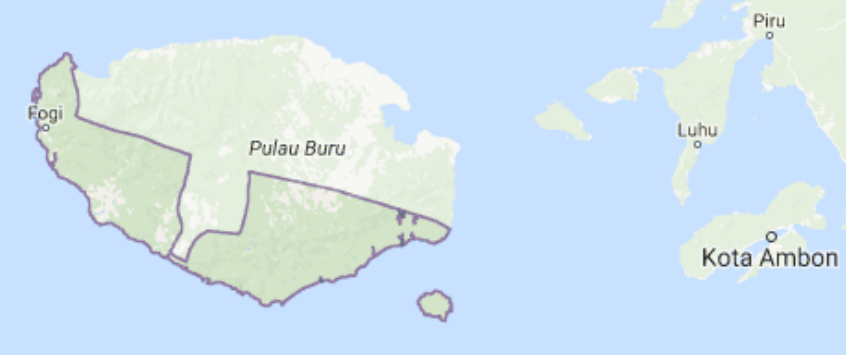

Gambar 1. Peta daerah pesisir Kabupaten Buru Selatan

\section{Rancangan Studi dan Sampel}

Survei ini menggunakan modifikasi desain EPI (Expanded Program on Immunization) Coverage Survey (World Health Organization: Department of
Immunization, 2008) dengan menggunakan 30 klaster (desa) dengan Rukun Warga (RW) sebagai sub-klaster. Total sampel dalam penelitian ini dihitung dengan menggunakan rumus perhitungan besar sampel untuk penelitian deskriptif kategorik dengan Persamaan 1.

$n=\frac{Z \alpha^{2} * P * Q}{d^{2}} x d e f$

dengan $\alpha=5 \%, P=50 \%$ (untuk mencapai nilai maksimal), $d=0,1$ dan deff $=2$. Dengan demikian minimal besar sampel yang diperlukan adalah 804 . Untuk mengantisipasi kejadian drop out, maka ditambah $10 \%$ menjadi 900 responden.

Pemilihan ke-30 klaster (desa) dilakukan dengan menggunakan metode PPS (Proportionate Probability to Size). Karena variabilitas ukuran desa, maka satu desa dapat memiliki lebih dari satu klaster, seperti di Desa Leksula (Kecamatan Leksula) dan Namrole (Kecamatan Namrole). Setelah dilakukan pemilihan klaster, dilakukan pemilihan sub-klaster (RW) dengan menggunakan metode simple random sampling.

\section{Pemilihan Responden}

Di setiap RW, enumerator melakukan kunjungan rumah hingga diperoleh 30 responden. Pemilihan rumah di setiap RW dilakukan dengan pemilihan arah jalan secara acak, menggambar lokasi rumah di arah yang terpilih, serta memilih rumah pertama dengan simple random sampling. Rumah kedua adalah rumah yang pintu depannya paling dekat dengan pintu depan rumah pertama dan seterusnya sampai enumerator. Bila di dalam rumah dijumpai lebih dari satu calon responden yang memenuhi kriteria, maka satu responden dipilih secara acak. Responden adalah kepala keluarga usia 20-65 tahun dan/atau pasangannya. Dari 900 responden yang diwawancarai, hanya 899 responden yang disertakan dalam analisis ini. Satu responden dikeluarkan karena tidak memenuhi kriteria usia yang ditentukan. Tidak ada responden yang menolak diwawancarai.

\section{Tim Pengumpul Data}

Sebelum pengumpulan data dilakukan, seluruh tenaga pengumpul data mendapatkan pelatihan dari tim peneliti di Fakultas Kedokteran Universitas Pattimura mengenai metodologisampling, cara pengisian kuesioner, serta prosedur wawancara. Satu tim pengumpul data bertanggung jawab untuk melakukan pengumpulan data di satu klaster selama satu hari. Setiap tim terdiri dari seorang pemeriksa fisik (dokter) dan tiga enumerator (mahasiswa Fakultas Kedokteran, Universitas Pattimura) yang bertugas melakukan wawancara menggunakan kuesioner, membantu pemeriksaan fisik, melakukan 
pemeriksaan darah (kadar kolesterol, gula darah, dan asam urat) dan pengukuran antropometri.

\section{Instrumen Penelitian}

Variabel yang digunakan dalam penelitian ini berasal dari kuesioner terstruktur yang berisi keterangan individu dan rumah tangga. Kuesioner ini memuat berbagai topik pertanyaan: (a) Identitas; (b) Latar belakang sosial ekonomi; (c) Fasilitas rumah; (d) Ketahanan pangan; (d) Kebiasaan; (e) Riwayat Penyakit keluarga; ( $f$ ) Riwayat penyakit; (g) Riwayat reproduksi (untuk wanita usia 20-49 tahun); (h) Riwayat pengobatan; (i) Riwayat pemakaian obat tradisional; (j) Pemeriksaan fisik; dan (k) Keadaan Umum.

\section{Variabel yang Dianalisis}

Variabel tergantung dalam analisis ini adalah status ketahanan pangan (tahan pangan vs. rawan pangan). Status ketahanan pangan dinilai dengan kuesioner standar US Household Food Security/Hunger Survey Module (USFSSM) (Bickel dkk., 2000; Usfar dkk., 2007). Variabel status ketahanan pangan dibentuk dari enam pertanyaan yang ditampilkan dalam Tabel 1 .
Berbagai variabel di tingkat lingkungan, rumah tangga dan individu disertakan dalam analisis. Di tingkat lingkungan, variabel kecamatan dibentuk berdasarkan kecamatan asal responden. Di tingkat rumah tangga, enam variabel disertakan: (1) indeks kekayaan rumah tangga, (2) pendapatan rumah tangga, (3) status pembayaran kepesertaan iuran kesehatan, (4) jumlah anggota rumah tangga, (5) penerima raskin dan 6) kepadatan anggota rumah tangga dalam rumah. Indeks kekayaan rumah tangga dibuat dengan menggunakan Principal Component Analysis (PCA) dengan menggunakan variabel aset yaitu kepemilikan sepeda, motor, perahu non mesin, perahu bermesin, televisi, pendingin ruangan (AC), pemanas air, LPG 12 kg, kulkas, mobil, jamban, serta jenis bahan bakar dan sumber air minum. Di tingkat individu, lima variabel yang disertakan adalah: (1) tingkat pendidikan tertinggi, (2) usia, (3) jenis kelamin, (4) kebiasaan merekok dan (5) kebiasaan minum alkohol.

\section{Proses pengumpulan dan manajemen data}

Di setiap klaster, tim lapangan akan melakukan pemilihan rumah dan responden sesuai prosedur yang

Tabel 1. Distribusi jawaban responden pada setiap komponen pertanyaan ketahanan pangan (adaptasi kuesioner FSSM-US) (Bickel dkk., 2000)

\begin{tabular}{|c|c|c|c|}
\hline No & Pertanyaan & $\begin{array}{l}\text { Afirmasi } \\
(\%)\end{array}$ & $\begin{array}{c}\text { Negatif } \\
\text { (tidak/tidak pernah benar) } \\
(\%)\end{array}$ \\
\hline 1 & $\begin{array}{l}\text { "Makanan yang Anda beli sudah habis, dan Anda tidak punya uang } \\
\text { untuk membeli lagi". Dalam setahun terakhir, apakah pernyataan } \\
\text { tersebut benar, kadang benar atau tidak benar bagi keluarga } \\
\text { Anda? }\end{array}$ & 68,9 & 31,2 \\
\hline 2 & $\begin{array}{l}\text { "Anda tidak sanggup mengupayakan makan makanan yang } \\
\text { seimbang (nasi dengan sayur dan lauk/pauk) untuk keluarga". } \\
\text { Dalam setahun terakhir, apakah pernyataan tersebut benar, } \\
\text { kadang benar atau tidak benar bagi keluarga Anda? }\end{array}$ & 71,8 & 28,3 \\
\hline 3 & $\begin{array}{l}\text { Dalam setahun terakhir, apakah anda atau orang dewasa lain di } \\
\text { keluarga Anda pernah mengurangi jumlah (frekuesi) makan atau } \\
\text { tidak makan karena tidak cukup uang untuk membeli makanan? }\end{array}$ & 42,5 & 57,5 \\
\hline 4 & $\begin{array}{l}\text { Seberapa sering hal ini terjadi-hampir setiap bulan, dalam } \\
\text { beberapa bulan tapi tidak setiap bulan, atau hanya dalam } 1 \text { atau } \\
2 \text { bulan saja? }\end{array}$ & 34,0 & 66,0 \\
\hline 5 & $\begin{array}{l}\text { Dalam setahun terakhir, apakah Anda pernah makan kurang dari } \\
\text { porsi yang seharusnya (menurut Anda) dimakan karena tidak } \\
\text { punya uang untuk membeli makanan? }\end{array}$ & 41,3 & 58,7 \\
\hline 6 & $\begin{array}{l}\text { Dalam setahun terakhir, apakah Anda pernah merasa lapar tapi } \\
\text { tidak makan karena Anda tidak punya uang untuk membeli } \\
\text { makanan? }\end{array}$ & 34,5 & 65,5 \\
\hline
\end{tabular}


telah ditentukan. Sebelum pengumpulan data dilakukan, enumerator akan menjelaskan tujuan wawancara dan menanyakan kesediaan calon responden untuk diwawancarai dan diperiksa kesehatannya. Bila bersedia, responden diminta untuk menandatangani informed consent sebagai pernyataan kesediaan untuk diwawancarai dan terlibat dalam penelitian.

Setelah pengumpulan data dilakukan, proses editing dilakukan untuk memastikan tidak ada pertanyaan yang terlewat ataupun jawaban yang tidak konsisten/logis. Proses editing dilanjutkan dengan pemberian kode pada seluruh jawaban yang tertera pada kuesioner. Data entri dilakukan oleh tim entri secara independen di Fakultas Kedokteran Universitas Pattimura. Proses cleaning selanjutnya dilakukan untuk data yang telah dientri, sebelum data digunakan untuk analisis.

\section{Analisis data}

Pada tahap pertama, analisis univariat dilakukan untuk melihat distribusi setiap variabel yang digunakan. Hasil analsis ditampilkan dalam nilai absolut (n) dan persentase (\%). Di tahap kedua, tabel kontingensi dikembangkan untuk melihat distribusi setiap variabel yang diteliti berdasarkan status ketahanan pangan (bivariate). Analisis regresi logistik juga dilakukan untuk mendapatkan Odds Ratio (OR) dari hubungan antar dua variabel (tanpa mengontrol variabel lainnya) ini. Pada tahap terakhir, analisis regresi logistik secara multivariate dilakukan untuk menilai hubungan status ketahanan pangan dengan setiap variabel, dengan mengontrol variabel lainnya (adjusted OR atau aOR). Dalam analisis multivariat, teknik backward elimination diterapkan untuk mengeliminasi faktor yang secara statistik tidak berhubungan secara signifikan dengan status ketahanan pangan (menggunakan tingkat signifikansi 0,05). Seluruh analisis dilakukan dengan software STATA/MP 14.2 .

\section{Persetujuan etik}

Persetujuan etik penelitian ini diperoleh dari Komisi Etik Fakultas Kedokteran Universitas Pattimura, Ambon. Persetujun pengumpulan data di masyarakat juga diperoleh dari institusi Badan Kesatuan Bangsa dan Politik, Pemerintah Daerah Provinsi Maluku. Sebelum pengumpulan data dilakukan, tim lapangan memperoleh izin penelitian dari pimpinan adminstratif wilayah setempat (Kepala Desa dan Ketua RW). Bila bersedia untuk diwawancarai, setiap calon responden diminta kesediaannya untuk menandatangani formulir informed consent yang telah disiapkan.

\section{HASIL DAN PEMBAHASAN}

Analisis ini menggunakan informasi yang berasal dari 899 responden. Distribusi keseluruhan respondenberdasarkan karakteristik individu dan rumah tangga dapat dilihat pada Tabel 1 . Lebih dari $65 \%$ responden adalah perempuan; $46 \%$ responden berpendikan SD atau yang lebih rendah; dan lebih dari 79\% responden memiliki pendapatan kurang dari Upah Minimum Regional (UMR). Penelitian ini menunjukkan $63 \%$ resonden berasal dari rumah tangga yang memiliki lima atau lebih anggota keluarga dan $82,4 \%$ responden mengakui mendapatkan tunjangan beras untuk masyarakat miskin (Raskin).

Tabel 2. Karakteristik sosio-demografi dan status ketahanan pangan masyarakat pesisir di Kabupaten Buru Selatan, 2017

\begin{tabular}{|c|c|c|c|c|c|c|c|c|}
\hline \multirow{3}{*}{ Variabel } & \multirow{3}{*}{$\mathrm{n}$} & \multirow{3}{*}{$\%$} & \multicolumn{6}{|c|}{ Status ketahanan pangan } \\
\hline & & & \multicolumn{2}{|c|}{ Tahan pangan } & \multicolumn{2}{|c|}{$\begin{array}{l}\text { Rawan pangan } \\
\text { tanpa lapar }\end{array}$} & \multicolumn{2}{|c|}{$\begin{array}{l}\text { Rawan pangan } \\
\text { dengan lapar }\end{array}$} \\
\hline & & & $\mathrm{n}$ & $(\%)$ & $\mathrm{n}$ & $(\%)$ & $\mathrm{n}$ & $(\%)$ \\
\hline \multicolumn{9}{|l|}{ Kecamatan } \\
\hline Kepala Madan & 150 & 16,7 & 37 & $(24,7)$ & 52 & $(34,7)$ & 61 & $(40,7)$ \\
\hline Namrole & 239 & 26,6 & 86 & $(36,0)$ & 65 & $(27,2)$ & 88 & $(36,8)$ \\
\hline Ambalau & 150 & 16,7 & 20 & $(13,3)$ & 95 & $(63,3)$ & 35 & $(23,3)$ \\
\hline Leksula & 180 & 20,0 & 52 & $(28,9)$ & 68 & $(37,8)$ & 60 & $(33,3)$ \\
\hline Waesama & 180 & 20,0 & 82 & $(45,6)$ & 39 & $(21,7)$ & 59 & $(32,8)$ \\
\hline \multicolumn{9}{|c|}{ Indeks kekayaan rumah tangga } \\
\hline Sangat miskin & 189 & 21,0 & 33 & $(17,5)$ & 60 & $(31,7)$ & 96 & $(50,8)$ \\
\hline Miskin & 175 & 19,5 & 37 & $(21,1)$ & 81 & $(46,3)$ & 57 & $(32,6)$ \\
\hline
\end{tabular}




\begin{tabular}{|c|c|c|c|c|c|c|c|c|}
\hline \multirow{3}{*}{ Variabel } & \multirow{3}{*}{$\mathrm{n}$} & \multirow{3}{*}{$\%$} & \multicolumn{6}{|c|}{ Status ketahanan pangan } \\
\hline & & & \multicolumn{2}{|c|}{ Tahan pangan } & \multicolumn{2}{|c|}{$\begin{array}{c}\text { Rawan pangan } \\
\text { tanpa lapar }\end{array}$} & \multicolumn{2}{|c|}{$\begin{array}{r}\text { Rawan pangan } \\
\text { dengan lapar }\end{array}$} \\
\hline & & & $\mathrm{n}$ & $(\%)$ & $\mathrm{n}$ & $(\%)$ & $\mathrm{n}$ & $(\%)$ \\
\hline Menengah & 178 & 19,8 & 55 & $(30,9)$ & 68 & $(38,2)$ & 55 & $(30,9)$ \\
\hline Kaya & 178 & 19,8 & 68 & $(38,2)$ & 54 & $(30,3)$ & 56 & $(31,5)$ \\
\hline Sangat kaya & 179 & 19,9 & 84 & $(46,9)$ & 56 & $(31,3)$ & 39 & $(21,8)$ \\
\hline \multicolumn{9}{|l|}{ Pendapatan rumah tangga } \\
\hline$<U M R$ & 713 & 79,3 & 75 & $(28,3)$ & 73 & $(34,5)$ & 38 & $(37,2)$ \\
\hline$\geq$ UMR & 186 & 20,7 & 202 & $(40,3)$ & 246 & $(39,2)$ & 265 & $(20,4)$ \\
\hline \multicolumn{9}{|c|}{ Status pembayaran kepesertaan iuran kesehatan } \\
\hline Tidak membayar & 309 & 34,4 & 74 & $(23,9)$ & 116 & $(37,5)$ & 119 & $(38,5)$ \\
\hline Membayar & 590 & 65,6 & 203 & $(34,4)$ & 203 & $(34,4)$ & 184 & $(31,2)$ \\
\hline \multicolumn{9}{|l|}{ Jumlah anggota rumah tangga } \\
\hline$\leq 4$ & 333 & 37,0 & 106 & $(31,8)$ & 113 & $(33,9)$ & 114 & $(34,2)$ \\
\hline $5+$ & 566 & 63,0 & 171 & $(30,2)$ & 206 & $(36,4)$ & 189 & $(33,4)$ \\
\hline \multicolumn{9}{|l|}{ Penerima raskin } \\
\hline Terima & 741 & 82,4 & 213 & $(28,7)$ & 262 & $(35,4)$ & 266 & $(35,9)$ \\
\hline Tidak terima & 158 & 17,6 & 64 & $(40,5)$ & 57 & $(36,1)$ & 37 & $(23,4)$ \\
\hline \multicolumn{9}{|l|}{ Kepadatan ART dalam rumah } \\
\hline Kurang ideal & 740 & 82,3 & 34 & $(21,4)$ & 65 & $(40,9)$ & 60 & $(37,7)$ \\
\hline Ideal & 159 & 17,7 & 243 & $(32,8)$ & 254 & $(34,3)$ & 243 & $(32,8)$ \\
\hline \multicolumn{9}{|c|}{ Pendidikan tertinggi yang ditamatkan } \\
\hline Tidak sekolah/tidak tamat SD & 139 & 15,5 & 33 & $(23,7)$ & 59 & $(42,4)$ & 47 & $(33,8)$ \\
\hline Tamat SD & 279 & 31,0 & 71 & $(25,4)$ & 98 & $(35,1)$ & 110 & $(39,4)$ \\
\hline Tamat SMP & 124 & 13,8 & 38 & $(30,6)$ & 40 & $(32,3)$ & 46 & $(37,1)$ \\
\hline Tamat SMA & 233 & 25,9 & 85 & $(36,5)$ & 76 & $(32,6)$ & 72 & $(30,9)$ \\
\hline Akademi/universitas & 124 & 13,8 & 50 & $(40,3)$ & 46 & $(37,1)$ & 28 & $(22,6)$ \\
\hline \multicolumn{9}{|l|}{ Usia (dalam tahun) } \\
\hline $21-30$ & 180 & 20,0 & 61 & $(33,9)$ & 57 & $(31,7)$ & 62 & $(34,4)$ \\
\hline $31-40$ & 261 & 29,0 & 88 & $(33,7)$ & 86 & $(33,0)$ & 87 & $(33,3)$ \\
\hline $41-50$ & 221 & 24,6 & 68 & $(30,8)$ & 82 & $(37,1)$ & 71 & $(32,1)$ \\
\hline $51-60$ & 228 & 25,4 & 56 & $(24,6)$ & 89 & $(39,0)$ & 83 & $(36,4)$ \\
\hline \multicolumn{9}{|l|}{ Jenis Kelamin } \\
\hline Laki-laki & 311 & 34,6 & 93 & $(29,9)$ & 116 & $(37,3)$ & 102 & $(32,8)$ \\
\hline Perempuan & 588 & 65,4 & 184 & $(31,3)$ & 203 & $(34,5)$ & 201 & $(34,2)$ \\
\hline \multicolumn{9}{|l|}{ Kebiasaan merokok } \\
\hline Merokok & 226 & 25,1 & 220 & $(25,2)$ & 228 & $(40,3)$ & 225 & $(34,5)$ \\
\hline Tidak merokok & 673 & 74,9 & 57 & $(32,7)$ & 91 & $(33,9)$ & 78 & $(33,4)$ \\
\hline \multicolumn{9}{|l|}{ Kebiasaan minum alkohol } \\
\hline Minum & 126 & 14,0 & 42 & $(33,3)$ & 40 & $(31,7)$ & 44 & $(34,9)$ \\
\hline Tidak minum & 773 & 86,0 & 235 & $(30,4)$ & 279 & $(36,1)$ & 259 & $(33,5)$ \\
\hline
\end{tabular}




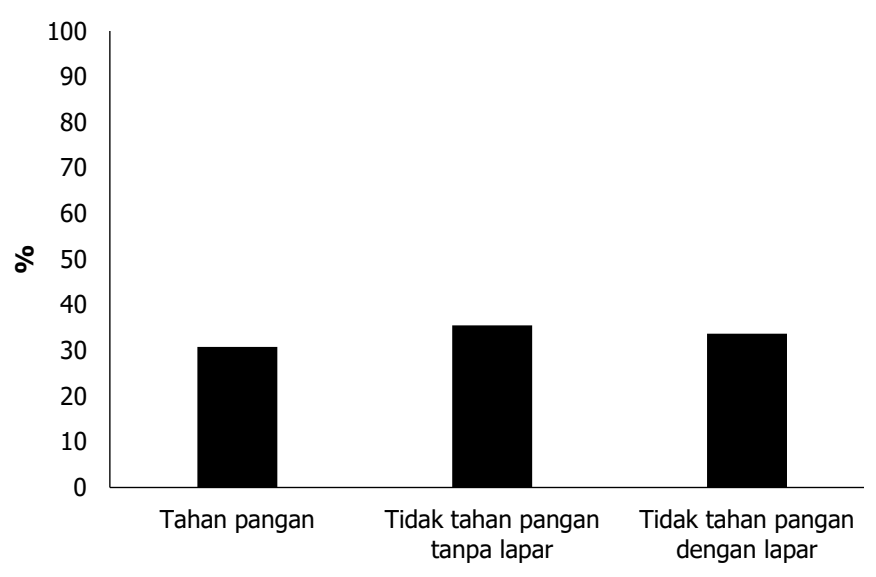

Gambar 2. Distribusi responden berdasarkan status ketahanan pangan, Kabupaten Buru Selatan, 2017

Berdasarkan status ketahanan pangan seperti pada Gambar 2, sebanyak $30.8 \%$ masyarakat yang tinggal di wilayah pesisir Kabupaten Buru Selatan tahan pangan, 35,5\% rawan pangan tanpa kondisi lapar dan $33,7 \%$ rawan pangan dengan kondisi lapar.
Sebanyak $71,8 \%$ responden menyebutkan kadang tidak sanggup mengupayakan makan makanan yang seimbang untuk keluarga dan 68,9\% responden menyebutkan "kadang makanan yang dibeli telah habis dan tidak punya uang untuk membeli lagi". Jawaban responden terhadap setiap komponen pertanyaan status ketahanan pangan dapat dilihat pada Tabel 2.

Frekuensi distribusi setiap variabel menurut status ketahanan pangan dapat dilihat pada Tabel 1 . Persentase tertinggi responden yang tahan pangan berasal dari Kecamatan Waesama (45,6\%) dan terendah di Kecamatan Ambalau (13,3\%). Responden dengan pendidikan terakhir akademi/universitas (40,3\%) lebih tahan pangan dibandingkan responden dengan tingkat pendidikan yang lebih rendah. Persentase masyarakat tahan pangan menurun seiring menurunnya indeks kekayaaan rumah tangga. Persentase responden yang tahan pangan juga lebih tinggi pada yang membayar iuran kepesertaan asuransi kesehatan (34,4\%) dan pada yang tidak menerima raskin (40,5\%).

Hasil analisis multivariat menujukkan faktor-faktor yang secara signifikan berhubungan dengan ketahanan

Tabel 3. Distribusi jawaban responden pada setiap komponen pertanyaan ketahanan pangan (adaptasi kuesioner FSSM-US) (Bickel dkk., 2000)

\begin{tabular}{|c|c|c|c|}
\hline No & Pertanyaan & $\begin{array}{c}\text { Afirmasi } \\
(\%)\end{array}$ & $\begin{array}{c}\text { Negatif } \\
\text { (tidak/tidak pernah benar) } \\
(\%)\end{array}$ \\
\hline 1 & $\begin{array}{l}\text { "Makanan yang Anda beli sudah habis, dan Anda tidak punya } \\
\text { uang untuk membeli lagr". Dalam setahun terakhir, apakah } \\
\text { pernyataan tersebut benar, kadang benar atau tidak benar bagi } \\
\text { keluarga Anda? }\end{array}$ & 68,9 & 31,2 \\
\hline 2 & $\begin{array}{l}\text { "Anda tidak sanggup mengupayakan makan makanan yang } \\
\text { seimbang (nasi dengan sayur dan lauk/pauk) untuk keluarga". } \\
\text { Dalam setahun terakhir, apakah pernyataan tersebut benar, } \\
\text { kadang benar atau tidak benar bagi keluarga Anda? }\end{array}$ & 71,8 & 28,3 \\
\hline 3 & $\begin{array}{l}\text { Dalam setahun terakhir, apakah anda atau orang dewasa lain di } \\
\text { keluarga Anda pernah mengurangi jumlah (frekuesi) makan atau } \\
\text { tidak makan karena tidak cukup uang untuk membeli makanan? }\end{array}$ & 42,5 & 57,5 \\
\hline 4 & $\begin{array}{l}\text { Seberapa sering hal ini terjadi-hampir setiap bulan, dalam } \\
\text { beberapa bulan tapi tidak setiap bulan, atau hanya dalam } 1 \text { atau } \\
2 \text { bulan saja? }\end{array}$ & 34,0 & 66,0 \\
\hline 5 & $\begin{array}{l}\text { Dalam setahun terakhir, apakah Anda pernah makan kurang dari } \\
\text { porsi yang seharusnya (menurut Anda) dimakan karena tidak } \\
\text { punya uang untuk membeli makanan? }\end{array}$ & 41,3 & 58,7 \\
\hline 6 & $\begin{array}{l}\text { Dalam setahun terakhir, apakah Anda pernah merasa lapar tapi } \\
\text { tidak makan karena Anda tidak punya uang untuk membeli } \\
\text { makanan? }\end{array}$ & 34,5 & 65,5 \\
\hline
\end{tabular}


Tabel 4. Faktor-faktor yang berhubungan dengan ketahanan pangan masyarakat pesisir di Kabupaten Buru Selatan, 2017

\begin{tabular}{|c|c|c|c|c|c|c|c|c|c|c|c|}
\hline \multirow[b]{2}{*}{ Variabel } & \multicolumn{6}{|c|}{ Univariate } & \multicolumn{5}{|c|}{ Multivariate } \\
\hline & OR & $\begin{array}{c}95 \% \\
\text { CI }\end{array}$ & & & & $p$ & OR & $95 \%$ C & & & $p$ \\
\hline \multicolumn{12}{|l|}{ Tingkat lingkungan } \\
\hline \multicolumn{12}{|l|}{ Kecamatan } \\
\hline Kepala Madan & 1,00 & & & & & & 1,00 & & & & \\
\hline Namrole & 1,72 & $(1,09$ & - & $2,71)$ & 0,020 & & 1,37 & $(0,85$ & - & $2,20)$ & 0,195 \\
\hline Ambalau & 0,47 & $(0,26$ & - & $0,86)$ & 0,014 & & 0,62 & $(0,33$ & - & $1,15)$ & 0,131 \\
\hline Leksula & 1,24 & $(0,76$ & - & $2,03)$ & 0,390 & & 1,04 & $(0,62$ & - & $1,74)$ & 0,877 \\
\hline Waesama & 2,56 & $(1,59$ & - & $4,10)$ & $<0,001$ & & 2,16 & $(1,33$ & - & $3,52)$ & 0,002 \\
\hline \multicolumn{12}{|l|}{ Tingkat rumah tangga } \\
\hline \multicolumn{12}{|l|}{ Indeks kekayaan rumah tangga } \\
\hline Sangat miskin & 1,00 & & & & & & 1,00 & & & & \\
\hline Miskin & 1,27 & $(0,75$ & - & $2,14)$ & 0,374 & & 1,29 & $(0,75$ & - & $2,20)$ & 0,358 \\
\hline Menengah & 2,11 & $(1,29$ & - & $3,46)$ & 0,003 & & 1,76 & $(1,06$ & - & $2,93)$ & 0,029 \\
\hline Kaya & 2,92 & $(1,80$ & - & $4,73)$ & $<0,001$ & & 2,47 & $(1,50$ & - & $4,06)$ & $<0,001$ \\
\hline Sangat kaya & 4,18 & $(2,60$ & - & $6,73)$ & $<0,001$ & & 3,49 & $(2,13$ & - & $5,73)$ & $<0,001$ \\
\hline \multicolumn{12}{|l|}{ Pendapatan rumah tangga } \\
\hline$<$ UMR & 1,00 & & & & & & & & & & \\
\hline$\geq U M R$ & 1,71 & $(1,22$ & - & $2,39)$ & 0,002 & & & & & & \\
\hline \multicolumn{12}{|c|}{ Status pembayaran kepesertaan iuran kesehatan } \\
\hline Tidak membayar & 1,00 & & & & & & 1,00 & & & & \\
\hline Membayar & 1,67 & $(1,22$ & - & $2,27)$ & 0,001 & & 1,49 & $(1,07$ & - & $2,08)$ & 0,018 \\
\hline \multicolumn{12}{|l|}{ Jumlah anggota rumah tangga } \\
\hline$\leq 4$ & 1,00 & & & & & & & & & & \\
\hline $5+$ & 0,93 & $(0,69$ & - & $1,24)$ & 0,612 & & & & & & \\
\hline \multicolumn{12}{|l|}{ Penerima raskin } \\
\hline Terima & 1,00 & & & & & & & & & & \\
\hline Tidak Terima & 1,69 & $(1,18$ & - & $2,41)$ & 0,004 & & & & & & \\
\hline \multicolumn{12}{|c|}{ Kepadatan anggota rumah tangga dalam rumah } \\
\hline Kurang ideal & 1,00 & & & & & & 1,00 & & & & \\
\hline Ideal & 1,80 & $(1,19$ & - & $2,71)$ & 0,005 & & 1,55 & $(1,01$ & - & $2,39)$ & 0,047 \\
\hline \multicolumn{12}{|l|}{ Tingkat individu } \\
\hline \multicolumn{12}{|l|}{ Pendidikan } \\
\hline Tidak sekolah/tidak tamat SD & 1,00 & & & & & & & & & & \\
\hline Tamat SD & 1,10 & $(0,68$ & - & $1,76)$ & 0,704 & & & & & & \\
\hline Tamat SMP & 1,42 & $(0,82$ & - & $2,45)$ & 0,209 & & & & & & \\
\hline Tamat SMA & 1,84 & $(1,15$ & - & $2,96)$ & 0,011 & & & & & & \\
\hline Akademi/Universitas & 2,17 & $(1,28$ & - & $3,69)$ & 0,004 & & & & & & \\
\hline
\end{tabular}




\begin{tabular}{|c|c|c|c|c|c|c|c|c|}
\hline \multirow[b]{2}{*}{ Variabel } & \multicolumn{5}{|c|}{ Univariate } & \multicolumn{3}{|c|}{ Multivariate } \\
\hline & OR & $\begin{array}{c}95 \% \\
\text { CI }\end{array}$ & & & $p$ & OR & $95 \% \mathrm{CI}$ & $p$ \\
\hline \multicolumn{9}{|l|}{ Usia (dalam tahun) } \\
\hline $21-30$ & 1,00 & & & & & & & \\
\hline $31-40$ & 0,99 & $(0,66$ & $-1,48)$ & 0,970 & & & & \\
\hline $41-50$ & 0,87 & $(0,57$ & $-1,32)$ & 0,506 & & & & \\
\hline $51-60$ & 0,64 & $(0,41$ & $-0,41)$ & 0,039 & & & & \\
\hline \multicolumn{9}{|l|}{ Jenis Kelamin } \\
\hline Laki-laki & 1,00 & & & & & & & \\
\hline Perempuan & 1,07 & $(0,79$ & $1,44)$ & 0,668 & & & & \\
\hline \multicolumn{9}{|l|}{ Kebiasaan merokok } \\
\hline Merokok & 1,00 & & & & & & & \\
\hline Tidak Merokok & 1,44 & $(1,02$ & $-2,02)$ & 0,036 & & & & \\
\hline \multicolumn{9}{|c|}{ Kebiasaan minum alkohol } \\
\hline Minum & 1,00 & & & & & & & \\
\hline Tidak Minum & 0,87 & $(0,59$ & - 1,30$)$ & 0,509 & & & & \\
\hline
\end{tabular}

Menurut status pembayaran kepesertaan iuran kesehatan, responden yang membayar kepesertaan iuran kesehatan lebih tahan pangan dibandingkan mereka yang mendapatkan pembebasan pembayaran iuran dari pemerintah ( $\mathrm{aOR}=1,49,95 \% \mathrm{CI}: 1,07-2,08$, $\mathrm{p}=0,018$ ). Hasil analisis ini juga menunjukkan bahwa responden dari rumah dengan kepadatan anggota rumah tangga ideal ( $\geq 8 \mathrm{~m}^{2}$ per orang) secara signifikan lebih tahan pangan dibandingkan mereka dari rumah dengan kepadatan anggota rumah tangga yang kurang ideal (aOR=1,55, 95\%CI: 1,01-2,39, $p=0,047)$.

Studi ini menegaskan adanya hubungan yang signifikan antara status ekonomi dengan ketahanan pangan, seperti yang dilaporkan dalam berbagai penelitian sebelumnya (Abdullah dkk., 2017; Adam, 2011; Food and Agriculture Organization of the United Nations, 2013; Food and Agriculture Organization of the United Nations, 2017; Ke \& Ford-Jones, 2015; Mutisya dkk., 2015). Masyarakat dari rumah tangga dengan kondisi ekonomi baik lebih memiliki kemampuan membeli berbagai bahan pangan, termasuk pada saat harga beras di pasaran sedang meningkat. Peningkatan harga bahan pangan merupakan hal yang terjadi di Kabupaten Buru Selatan, terutama di wilayah dengan akses yang terbatas. Inilah yangdapat menjadi salah satu faktor yang menyebabkan masyarakat di Kecamatan Kepala Madan (salah satu kecamatan yang terjauh dari ibu kota kabupaten Buru Selatan) lebih rentan rawan pangan dibandingkan mereka dari Kecamatan Waesama.
Temuan ini menekankan pentingnya intervensi untuk meningkatkan kondisi ekonomi masyarakat. Data Badan Pusat Statistik pada tahun 2017 menunjukkan prevalensi penduduk miskin di Provinsi Maluku sebanyak $18,45 \%$ dan di Kabupaten Buru Selatan sebanyak 16,83\% (Badan Pusat Statistik, 2018). Selain program pengentasan kemiskinan jangka panjang yang perlu menjadi perhatian, dalam jangka pendek program bantuan sosial dan jaring pengaman sosial masih perlu diprioritaskan (Dewan Ketahanan Pangan - Kementerian Pertanian \& World Food Programme (WFP), 2015; Ke \& Ford-Jones, 2015). Di Indonesia, salah satu bantuan sosial adalah penyediaan beras Raskin, yang merupakan beras bersubsidi. Apabila bila beras yang disediakan juga adalah beras terfortifikasi, maka hal ini dapat membantu meningkatkan asupan gizi mikro masyarakat (Dewan Ketahanan Pangan - Kementerian Pertanian \& World Food Programme (WFP), 2015). Selain itu, program pemberian makanan di sekolah juga dilaporkan dapat membantu meningkatkan ketahanan pangan keluarga, dengan cara pemberian makanan gratis atau dengan harga yang minimal (Bartfeld \& Ahn, 2011; Roustit dkk., 2010).

Selain faktor ekonomi, salah satu faktor yang ditengarai berperan adalah pola makan masyarakat dewasa ini yang cenderung mengkonsumsi beras sebagai makanan pokok. Masyarakat juga lebih memilih mengonsumsi beras karena beras lebih mudah disimpan dan praktis dalam proses pengolahan. Mengingat kondisi 
masyarakat Kabupaten Buru Selatan yang tidak terbiasa berocok tanam padi, diperberat dengan kondisi geografis yang sulit, maka ketersediaan, akses dan keterjangkauan harga beras kadang dapat menjadi masalah. Dewasa ini, pemanfaatan pangan lokal, yang sebenarnya lebih tersedia dengan nilai gizi yang tinggi, sudah jauh berkurang. Kurangnya pengetahuan masyarakat tentang cara pengolahan dan penyimpangan pangan lokal turut mempengaruhi kondisi ini. Hasil observasi lapangan pada saat pengumpulan data menunjukkan sebagian masyarakat gemar mengkonsumsi makanan instan yang dianggap praktis, tidak memerlukan pengolahan yang lama, cenderung mudah diperoleh dan harga relatif terjangkau.

Berbagai kondisi ini menunjukkan diperlukannya kegiatan penyuluhan untuk mengedukasi masyarakat mengenai berbagai macam pangan lokal yang dapat dimanfaatkan, termasuk cara penyimpanan dan pengolahan untuk mempertahankan nilai gizi yang dikandungnya. Selain itu, pendekatan multisektoral sangatlah penting (Dewan Ketahanan Pangan Kementerian Pertanian \& World Food Programme (WFP), 2015). Peran serta pihak pemerintah maupun swasta, institusi pendidikan, lembaga swadaya masyarakat diperlukan untuk melakukan berbagai kegiatan edukasi dan pemberdayaan masyarakat.

Dalam penelitian ini, juga ditemukan bahwa distribusi responden berdasarkan tekanan darah dan kadar kolesterol dalam darah tidak berbeda secara signifikan menurut status ketahanan pangannya. Walaupun demikian, persentase responden yang mengalami hipertensi (tekanan sistole $<120 \mathrm{mmHg}$ ) lebih tinggi pada kelompok yang rawan pangan $(68,9 \%)$ dibandingkan kelompok yang tahan pangan $(63,9 \%)$ (Gambar 3).

Hal yang sama juga dijumpai dengan kadar kolesterol darah. Meskipun tidak berbeda secara signifikan, persentase responden yang mengalami peningkatan kadar kolesterol darah lebih tinggi pada

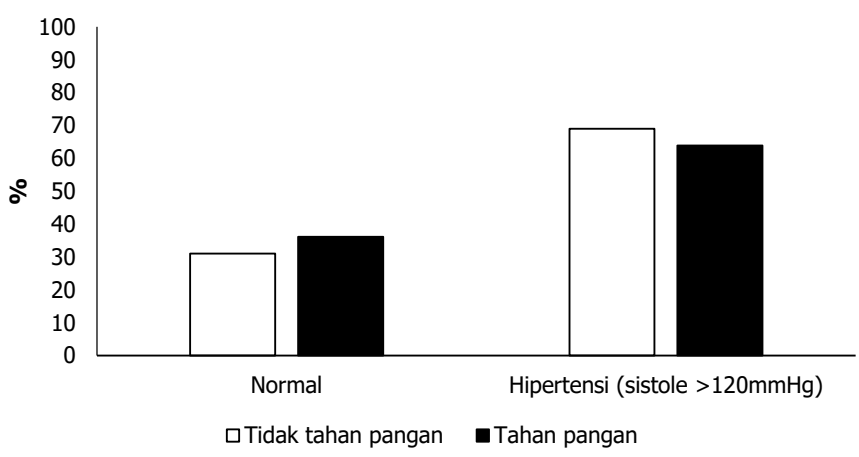

Gambar 3. Distribusi responden berdasarkan status ketahanan pangan dan tekanan darah sistolik

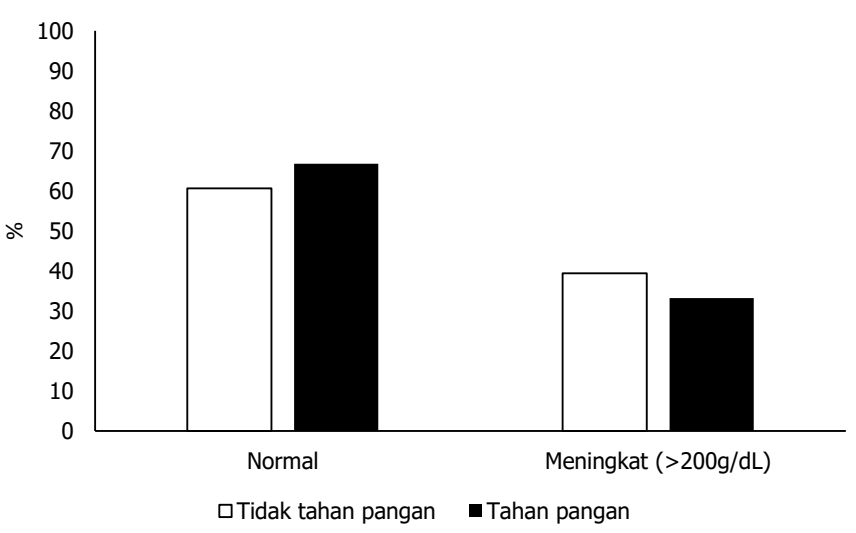

Gambar 4. Distribusi responden berdasarkan status ketahanan pangan dan kadar kolesterol dalam darah

responden yang mengalami rawan pangan $(39,4 \%)$ dibandingkan mereka yang tahan pangan $(33,2 \%)$ (Gambar 4). Temuan ini juga didukung oleh berbagai studi sebelumnya yang melaporkan adanya hubungan antara status ketahanan pangan dengan berbagai penyakit kronik (Berkowitz dkk., 2007)

Temuan-temuan ini menunjukkan bahwa tenaga kesehatan juga diharapkan dapat berperan aktif dalam mengedukasi masyarakat dalam membuat pilihan makan yang sehat bagi anak dan keluarga. Setiap kontak dengan masyarakat menjadi kesempatan yang berharga dan perlu dimanfaatkan secara optimal oleh untuk kegiatan edukasi, dan juga untuk menghubungkan masyarakat dengan layanan sosial yang tersedia, bila diperlukan.

Di samping itu, pengembangan media Komunikasi, Informasi dan Edukasi (KIE) termasuk di bidang kesehatan dengan bahasa yang mudah dipahami menyesuaikan budaya lokal yang ada juga dapat digunakan sebagai media yang efektif untuk mengedukasi masyarakat (Upadhyay \& Palanivel, 2011). Salah satu contoh pengembangan media KIE yang dapat dilakukan adalah pengembangan materi tentang cara pemberian makanan anak dan keluarga yang dapat digunakan oleh tenaga kesehatan ketika berkontak dengan masyarakat.

\section{Keterbatasan dan kelebihan penelitian}

Jumlah sampel cukup besar sehingga dapat digunakan untuk menganalisis hubungan antara status ketahanan pangan dengan berbagai variabel di tingkat lingkungan, rumah tangga dan individu. Datayang diperolehjuga secara spesifik mewakili kondisi masyarakat yang tinggal di wilayah pesisi Kabupaten Buru Selatan sehingga hasil yang diperoleh dapat digunakan secara optimal oleh para pemegang 
program yang terkait. Penelitian ini memiliki beberapa keterbatasan yang perlu diperhatikan. Seperti halnya karakteristik survei potong lintang lainnya, hasil analisis tidak menggambarkan hubungan sebab akibat. Selain itu, informasi yang dikumpulkan bergantung pada ingatan responden semata. Analisis yang dilakukan juga terbatas pada variabel yang tersedia. Beberapa variabel yang berhubungan seperti akses dan ketersediaan bahan pangan di dalam rumah tangga namun tidak tersedia tidak disertakan dalam analisis. Walaupun demikian, keterbatasan ini, tidak mengurangi validitas analisis yang dilakukan.

\section{KESIMPULAN}

Hasil studi ini menunjukkan persentase masyarakat pesisir yang mengalami rawan pangan di Kabupaten Buru Selatan masih tinggi. Faktor ekonomi memiliki peranan penting terhadap status ketahanan pangan masyarakat. Berbagai intervensi yang dapat dilakukan baik dalam jangka pendek dan panjang, termasuk upaya pengurangan kemiskinan, penyediaan pangan bersubsidi yang telah terfortifikasi, maupun bantuan pangan bagi masyarakat miskin. Upaya edukasi perlu mendapat perhatian besar dalam mengurangi ketergantung masyarakat pada beras sebagai makan pokok. Peningkatan pengetahuan masyarakat tentang berbagai bahan pangan lokal yang bergizi yang dapat dimanfaatkan, serta cara penyimpanan dan pengolahannya perlu dilakukan. Kerjasama lintas sektor sangat diperlukan dari berbagai sektor, termasuk pertanian dan kesehatan, pihak pemerintah maupun swasta, lembaga swadaya masyarakat dan berbagai pihak lainnya untuk mengurangi kerawanan pangan pada masyarakat pesisir di Kabupaten Buru Selatan, dan Provinsi Maluku pada umumnya.

\section{UCAPAN TERIMA KASIH}

Ucapan terima kasih diberikan kepada Dekan Fakultas Kedokteran Universitas Pattimura dan seluruh staf yang telah mendukung kegiatan penelitian ini. Kami juga mengucapkan banyak terima kasih kepada Pemerintah Provinsi Maluku, Kabupaten Buru Selatan serta pimpinan di setiap kecamatan, desa dan RW yang telah memberikan dukungannya. Terima kasih tak terhingga juga kami ucapkan kepada masyarakat wilayah Kabupaten Buru Selatan termasuk para responden yang telah bersedia untuk diwawancarai. Penelitian ini juga tidak akan dapat terlaksana tanpa komitmen dan kerja keras dari seluruh tim pengumpul data.

\section{KONFLIK KEPENTINGAN}

Tidak ada konflik kepentingan dalam penelitian ini.

\section{DAFTAR PUSTAKA}

Abdullah, Zhou, D., Shah, T., Ali, S., Ahmad, W., Din, I. U., Ilyas, A. (2017). Factors affecting household food security in rural northern hinterland of Pakistan. Journal of the Saudi Society of Agricultural Sciences. https://doi. org/10.1016/j.jssas.2017.05.003

Adam, F. P. (2011). Penduduk dan ketahanan pangan di pulau kecil: kontribusi faktor yang mempengaruhinya. Pengembangan Pulau-pulau Kecil.

Anonim. (2012). Undang-Undang Republik Indonesia No 18 Tahun 2012 tentang Pangan.

Anonim. (2017). Global Food Security Index: Indonesia. Retrieved from http://foodsecurityindex.eiu.com/ Country/Details - Indonesia.

Badan Pusat Statistik. (2018). Persentase Penduduk Miskin di Provinsi Maluku Menurut Kabupaten/Kota, 2005 2017. Retrieved from https://maluku.bps.go.id/ dynamictable/2018/01/11/62/persentase-pendudukmiskin-di-provinsi-maluku-menurut-kabupatenkota-2005---2017.html.

Bartfeld, J. S., \& Ahn, H. M. (2011). The school breakfast program strengthens household food security among low-income households with elementary school children. J Nutr, 141(3), 470-475. https://doi.org/10.3945/ jn.110.130823.

Berkowitz, S. A., Baggett, T. P., Wexler, D. J., Huskey, K. W., \& Wee, C. C. (2013). Food insecurity and metabolic control among U.S. adults with diabetes. Diabetes Care, 36(10), 3093-3099. https://doi.org/10.2337/dc13-0570.

Bickel, G., Nord, M., Price, C., Hamilton, W., \& Cook, J. (2000). Guide to Measuring Household Food Security (U. S. D. o. Agriculture Ed.). Alexandria, USA: United States Department of Agriculture.

Black, M. M. (2012). Integrated strategies needed to prevent iron deficiency and to promote early child development. J Trace Elem Med Biol, 26(2-3), 120-123. https://doi. org/10.1016/j.jtemb.2012.04.020.

Blue Bird Jernigan, V., Wetherill, M. S., Hearod, J., Jacob, T., Salvatore, A. L., Cannady, T., dkk. (2017). Food insecurity and chronic diseases among american indians in rural oklahoma: the thrive study. Am J Public Health, 107(3), 441-446. https://doi.org/10.2105/ajph.2016.303605.

Dewan Ketahanan Pangan - Kementerian Pertanian, \& World Food Programme (WFP). (2015). Peta Ketahanan dan Kerentanan Pangan Indonesia 2015. Jakarta: Dewan Ketahanan Pangan - Kementerian Pertanian dan World Food Programme (WFP). 
Dinas Ketahanan Pangan Provinsi Maluku. (2017). Peta Ketahanan Dan Kerentanan Pangan Provinsi Maluku 2017. Ambon: Dinas Ketahanan Pangan Provinsi Maluku.

Dubois, L., Francis, D., Burnier, D., Tatone-Tokuda, F., Girard, M., Gordon-Strachan, G., dkk. (2011). Household food insecurity and childhood overweight in Jamaica and Quebec: a gender-based analysis. BMC Public Health, 11, 199. https://doi.org/10.1186/1471-2458-11-199.

Food and Agriculture Organization of the United Nations. (2013). The state of food insecurity in the world: the mutliple dimension of food security. Rome: Food and Agriculture Organization of the United Nations.

Food and Agriculture Organization of the United Nations. (2017). The state of food and agriculture: leveraging food systems for inclusive rural transformation. Rome: Food and Agriculture Organization of the United Nations.

Garner, A. S., \& Shonkoff, J. P. (2012). Early childhood adversity, toxic stress, and the role of the pediatrician: translating developmental science into lifelong health. Pediatrics, 129(1), e224-231. https://doi.org/10.1542/ peds.2011-2662.

Gundersen, C., Lohman, B. J., Eisenmann, J. C., Garasky, S., \& Stewart, S. D. (2008). Child-specific food insecurity and overweight are not associated in a sample of 10- to 15-year-old low-income youth. J Nutr, 138(2), 371-378.

Ke, J., \& Ford-Jones, E. L. (2015). Food insecurity and hunger: A review of the effects on children's health and behaviour. Paediatrics \& Child Health, 20(2), 89-91. https://doi. org/10.1093/pch/20.2.89

Mannaf, M. \& Uddin Md. Taj. (2012). Socioeconomic factors influencing food security status of maize growing households in selected areas of Bogra District. Bangladesh J. Agric. Econs., XXXV,(1\&2), 177-187.

McIntyre, L., Williams, J. V., Lavorato, D. H., \& Patten, S. (2013). Depression and suicide ideation in late adolescence and early adulthood are an outcome of child hunger. J Affect Disord, 150(1), 123-129. https://doi.org/10.1016/j. jad.2012.11.029.

McLaughlin, K. A., Green, J. G., Alegria, M., Jane Costello, E., Gruber, M. J., Sampson, N. A., dkk. (2012). Food insecurity and mental disorders in a national sample of U.S. adolescents. J Am Acad Child Adolesc Psychiatry, 51(12), 1293-1303. https://doi.org/10.1016/j. jaac.2012.09.009.
Mutisya, M., Kandala, N.-b., Ngware, M. W., \& Kabiru, C. W. (2015). Household food (in)security and nutritional status of urban poor children aged 6 to 23 months in Kenya. BMC Public Health, 15, 1052. https://doi. org/10.1186/s12889-015-2403-0.

Roustit, C., Hamelin, A. M., Grillo, F., Martin, J., \& Chauvin, P. (2010). Food insecurity: could school food supplementation help break cycles of intergenerational transmission of social inequalities? Pediatrics, 126(6), 1174-1181. https://doi.org/10.1542/peds.2009-3574.

Seligman, H. K., Bindman, A. B., Vittinghoff, E., Kanaya, A. M., \& Kushel, M. B. (2007). Food Insecurity is Associated with Diabetes Mellitus: Results from the National Health Examination and Nutrition Examination Survey (NHANES) 1999-2002. Journal of General Internal Medicine, 22(7), 1018-1023. https://doi.org/10.1007/ s11606-007-0192-6.

Seligman, H. K., Laraia, B. A., \& Kushel, M. B. (2010). Food Insecurity Is Associated with Chronic Disease among Low-Income NHANES Participants. The Journal of Nutrition, 140(2), 304-310. https://doi.org/10.3945/ jn.109.112573.

United Nations. (2015). Sustainable Development Goals. Retrieved from https://sustainabledevelopment. un.org/?menu=1300.

Upadhyay, R. P., \& Palanivel, C. (2011). Challenges in Achieving Food Security in India. Iranian Journal of Public Health, 40(4), 31-36.

Usfar AA, Fahmida U, \& Februhartanty J. (2007). Household food security status measured by the US-Household Food Security/Hunger Survey Module (US-FSSM) is in line with coping strategy indicators found in urban and rural Indonesia. Asia Pacific Journal of Clinical Nutrition, 16(2), 368-374.

Wambua, B. N., Omoke, K. J., \& Mutua, T. M. (2014). Effects of Socio-Economic Factors on Food Security Situation in Kenyan Dry lands Ecosystem. Asian Journal of Agricultural and Food Sciences, 2(1).

World Health Organization: Department of Immunization, V. a. B. (2008). Training for mid-level managers (MLM). Module 7: The EPI Coverage Survey. Retrieved from http://apps.who.int/iris/bitstream/10665/70184/7/ WHO_IVB_08.07_eng.pdf. 